\title{
Relationship Between Nurses Job Satisfaction And Quality Of Nursing Care In Damietta Oncology Institute
}

\author{
Nawall Mohamed Ali Shaheen; Seham Ibrahim Hamouda; \\ Fathya Abdelrazek Afify; Hossam Darwesh Abu Gadalla
}

${ }^{1}$ B.Sc of Nursing - Suez Canal University; ${ }^{2}$ Professor of Nursing Administration-
Faculty of Nursing - Tanta University; ${ }^{3}$ Lecturer of Nursing Administration- Faculty of
Nursing-Suez Canal University; ${ }^{4}$ Consultant of Oncology-Damietta Oncology Institute

\begin{abstract}
Background: Nurses are leaving their profession as a result of low levels of job satisfaction arising from their working conditions. Job satisfaction of staff nurses directly influences quality of care. Aim: the aim of the study was to study the correlation between the nurse's job satisfaction and quality of nursing care in Damietta Oncology Institute. Subject and Methods: A correlational descriptive study was used. Total sample included 45 nurses working in inpatient departments. Data were collected by using three different tools, job satisfaction questionnaire, chemotherapy administration observational checklist and pre- postoperative care observational checklists. Results: The results of the study revealed that the low level of job satisfaction among participating nurses was due to the lack of advancement and skills development, work environment safety, poor salaries and lack of responsibilities. Whereas, level of quality of nursing care showed was a moderate level. This performance was regarding preoperative nursing care and postoperative nursing care. Recommendation: these findings recommend establishing rules for promotion policies and salary scales for each of the different categories of nurses, develop training programs for nurses based on patients needs.
\end{abstract}

Key Words: Job satisfaction, quality of nursing care, cancer patient, preoperative care, postoperative, chemotherapy administration skills. 


\section{INTRODUCTION}

Job satisfaction is essential for the effectiveness of any health care organization because it directly influences the quality of the services offered (Nigy, 2006). In addition, nursing departments have the largest numbers of employees and most of them provide direct care to the patients. Therefore, it is important to direct the attention towards their needs and to increase and sustain the job satisfaction among the nurses. Improved job satisfaction results in high quality of patient's care and contributes to the overall quality of health services (Maria, Pavlos, Eleni \& Thamme, 2010).

Job satisfaction is the collection of feelings and beliefs that people have about their current job (George \& Jones, 2008). There are many factors that contribute to job satisfaction. These factors include hygiene factors such as hospital policy, degree of supervision, internal relationships, work conditions, safety and salary. The second continuum of motivating factors includes work achievement, recognition, work challenges, responsibility, advancement and possibility of growth (Marquis \& Huston, 2009).

Quality of patient's care and nurse's satisfaction are proportionately related to each other. Satisfied nurses are ready to provide a better quality of patient's care (Nigy, 2006; Siddiqui, 2013). Quality of healthcare is the extent to which the health services provided to individuals and patient populations improve the desired health outcomes (Medical Education Institute, 2012). There are three basic domains for quality: structure, process, and outcome. Structure represents the basic characteristics of physicians, hospitals, other professionals, and other facilities. In addition, process suggests that quality is determined by having the right things done in the right way. Process raises questions such as: Was the mammogram done for a woman at risk for breast cancer? The third dimension is the outcome which reflects the end result of care (Clancy, 2009).

Quality of care provided to cancer patients should be highlighted because cancer is a leading cause of death worldwide. There are four standard methods for treatment of cancer: surgery, chemotherapy, radiotherapy, immunotherapy and biologic therapy. Surgery can be used to prevent, treat, stage and diagnose cancer. Whereas, chemotherapy is a type of cancer treatment that uses drugs to eliminate cancer cells. In addition, radiotherapy therapy uses certain types of energy to shrink tumors or eliminate cancer cells. It works by damaging a cancer cell's DNA, making it unable to multiply (Fayed, 2009). 
Additionally, oncology patients should be provided with high quality of care delivery system that is accessible to all patients, including vulnerable and underserved populations. This system should also reward cancer care teams for providing patientcentered, high-quality care and eliminating wasteful interventions (Institute of Medicine, 2013). In Damietta Oncology Institute, nurses who provide care for cancer patients, monitor their physical conditions, administer chemotherapy and pain medications. Also it's worth mentioning that oncology is one of the most stressful fields in nursing, which makes nurses suffer from psychological problems and need to be rewarded from the job.

\section{SUBJECT AND METHODS:}

Aim of the present study was to determine the relationship between nurse's job satisfaction and quality of nursing care in Damietta Oncology Institute.

\section{Research Objectives is to:}

1- Determine level of job satisfaction among the staff nurses in Damietta Oncology Institute.

2- Assess level of quality performance of nursing care among the staff nurses in Damietta Oncology Institute.

3- Find out the relationship between nurses job satisfaction and quality performance of nursing care in Damietta Oncology Institute.

\section{Research design:}

A correlational descriptive study

\section{Settings of the study:}

This study was carried out at all inpatient departments in Damietta Oncology Institute, which included two departments that provided chemotherapy treatments; Internal Medicine department (both male and female wards) and one-day chemotherapy administration unit. Two surgical wards (male and female) and a postoperative intensive care unit were also included.

\section{Study population:}

This study included all the staff nurses, 45 nurses, at the inpatient departments. representing all the nurse manpower at these departments . 


\section{Tools for data collection:}

Data of this study was collected using three different tools; Job satisfaction questionnaire, chemotherapy administration observational checklist and pre- and postoperative care observational checklist.

\section{Tool (I): Job Satisfaction Questionnaire:}

This questionnaire sheet was used to measure level of job satisfaction among the staff nurses. It is adopted from Mohamed (2005) based on the Herzberg's two factor theory, and it consists of two main parts:

\section{Part (1):}

It included items related to personal and job characteristics of staff nurses, such as age, education, years of experience, department, etc...

\section{Part (II):}

It was composed of 92 items grouped along a continuum of rating scale under two types of factors. (Appendix 1)

\section{A) Hygiene factors:}

It included 60 items categorized under five divisions; salary and incentives (10 statements), work environment (21 statements), internal hospital relations (13 statements), supervision (6 statements) and hospital administration policy (10 statements).

\section{B) Motivating factors:}

It included 32 items categorized under five divisions; job achievement ( 8 statements), job appreciation (7 statements), job challenge (6 statements), job responsibility (3 statements) and job promotion (8 statements).

\section{Scoring System:}

The scoring system for each statement was designed into three levels; dissatisfied, sometimes satisfied and satisfied. "Satisfied" scored (2), "Sometimes satisfied" scored (1), and "dissatisfied" scored (zero). The subjects' responses were categorized as highly satisfied (scores > 66\%); moderately satisfied (scores 33\% - 66\%) and poorly satisfied (scores < 33\%) ( Abdelrazik, 2000).

\section{Tool (II): Chemotherapy Administration Observational Checklist}

This checklist was used to assess quality of nursing care regarding chemotherapy administration. It was developed by the researcher based on review related literature Potter (1995); Taylor et al. (2005) and Parkland Hospital System (2008). This tool 
consists of (35) statements categorized under two main dimensions namely as pretreatment intervention (17 items), and chemotherapy administration (18 items).

\section{Scoring System:}

The subject's responses were measured against a three levels rating scale. This scale consisted of three levels for each statement (zero, one, and two).zero: means that the nurse doesn't make the procedure, one :means that the nurse makes incomplete procedure and two: means that the nurse makes complete procedure.

\section{Tool (III): Pre-postoperative care observational check list:}

This checklist was used to assess the quality of nursing care regarding patient pre- and post-operative care. It was developed by the researcher based on literature review based on Potter (1995); Taylor et al. (2005). This tool consists of two parts as follows:

\section{Part (I):}

This part covers preoperative care activities. It consists of 34 statements categorized under three main dimensions namely as on admission (20 items), day before surgery (three) and day of surgery (11).

\section{Part (II):}

This part covers postoperative care checklist. It consists of 41 statements categorized under three main dimensions namely as immediate cares after surgery (21 items), care of vital system (14 items) and health education to the patient before discharge (6 items).

\section{Scoring system:}

This checklist was measured against a rating scale. This scale was made up of three levels for each statement (zero, one, and two) zero: means that the nurse doesn't make the item, one: means that the nurse makes item but it is not complete and two: means that the nurse's performance is satisfactory.

\section{Field Work:}

The study was conducted using self-instruction job satisfaction questionnaire filled by staff nurses, which took three weeks. In addition, chemotherapy observational checklists to assess level of quality of chemotherapy administration skill by observing each nurse along one shift while giving chemotherapy to cancer patient.

In addition, pre- and postoperative care observational checklists were filled by the researcher observation. This checklist assesses level of quality of pre- and postoperative patient care. Intermittent observation along three shifts to each nurse 
was used to complete the checklist. The process of data collection took a period of three months from July 2012 to September 2012.

\section{Ethical Considerations:}

- An approval was obtained from the director of Oncology Institute before carrying out the study after explaining its aim.

- Oral consent was obtained from included participants after explaining the aim of the study to each one to be familiar with the importance of her/his participation.

- The aim of the study was explained to each participant included in the study to obtain her/his permission to participate.

- A brief explanation of the study was given to assure the nurses that the information obtained will be confidential and will be used only for the purpose of the study.

\section{RESULTS:}

Table (1) shows the personal and job characteristics of the participating nurses. It was found that the majority $(95.6 \%)$ of the nurses hold a nursing secondary diploma and more than three fourths of them $(75.6 \%)$ were aged less than thirty years old with a mean of (27.48 \pm 4.72$)$. Besides, nearly half of the nurses $(48.9 \%)$ have more than ten

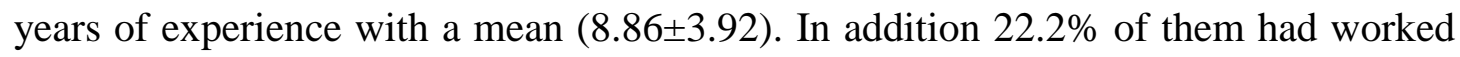
at private hospitals apart from the oncology field.

Table (2) clarifies that total mean percentage of nurses job satisfaction was (31.76\%). In this regard, work achievement as motivating factor scored the highest mean percentage (52.3\%), followed by degree of supervision and its type (47.3\%). In addition, fees and motives scored $40.0 \%$ as hygienic factors, and work challenge (37.6). On the other hand, advancement and skills development scored the least mean percentage in nurses satisfaction $(20.3 \%)$ as a motivating factor, followed by the responsibilities $(24.3 \%)$ while the hospital administration policy scored $24.3 \%$ as hygienic factors.

Figure (1) revealed that total mean in for of percentage of total quality of care among participating nurses was $62.20 \%$. In this regard, total quality of preoperative care scored $69.0 \%$ as the highest mean, followed by the mean of total quality of postoperative care $(64.5 \%)$. On the other hand, the mean of total quality of chemotherapy administration was $(52.75 \%)$ was the least mean percentage. 
Table (3) describes the relationship between nurse job satisfaction and the total quality of care among participating nurses. However no significant correlation between total job satisfaction and quality of nursing care was shown, it was found that there is a significant correlation between salary and incentive as hygienic factors of job satisfaction and the quality of preoperative care on admission and total quality of care. Also, there was a significant correlation between work environment and safety as hygienic factors of job satisfaction and quality of the pretreatment chemotherapy intervention. A significant correlations between hospital administration policy as hygienic factor and immediate care of postoperative care, care of body vital systems and total quality of postoperative care were also shown. Besides, there was significant correlation between the total qualities of chemotherapy administration and internal relationships as a hygienic factor and work achievements as motivating factors in addition to total job satisfaction. In addition, there was also significant correlation between total motivating factors and total chemotherapy administration in addition to total quality of care. 
Table (1) : personal and job characteristics of participating nurses in Damietta Oncology Institute.

\begin{tabular}{|c|c|c|}
\hline \multicolumn{3}{|l|}{$(\mathrm{N}=45)$} \\
\hline Items & No & $\%$ \\
\hline \multicolumn{3}{|l|}{ Age group:(years) } \\
\hline$\leq 30$ & 34 & $75.6 \%$ \\
\hline \multirow{2}{*}{$\begin{array}{l}>30 \\
(\text { Mean } \pm \text { SD) }\end{array}$} & 11 & $24.4 \%$ \\
\hline & & $(27.48 \pm 4.72)$ \\
\hline \multicolumn{3}{|l|}{ Educational :(years) } \\
\hline Associate nursing diploma & 2 & $4.4 \%$ \\
\hline Nursing secondary diploma & 43 & $95.6 \%$ \\
\hline \multicolumn{3}{|l|}{ Experience : } \\
\hline$<5$ & 10 & $22.2 \%$ \\
\hline $5-10$ & 13 & $28.9 \%$ \\
\hline$>10$ & 22 & $48.9 \%$ \\
\hline$($ Mean \pm SD $)$ & & $(8.86 \pm 3.92)$ \\
\hline \multicolumn{3}{|l|}{ Department } \\
\hline Surgical & 8 & $17.8 \%$ \\
\hline Medical & 22 & $48.9 \%$ \\
\hline ICU & 15 & $33.3 \%$ \\
\hline \multicolumn{3}{|l|}{ Working at private hospitals } \\
\hline $\begin{array}{l}\text { Worked at private hospital in Egypt out of the } \\
\text { oncology field. }\end{array}$ & 10 & $22.2 \%$ \\
\hline $\begin{array}{l}\text { Worked at private hospital in the Arabic region out of } \\
\text { the oncology field. }\end{array}$ & 1 & $2.2 \%$ \\
\hline
\end{tabular}


Table (2): Total mean percentage of factors affecting level of job satisfaction among participating nurses at Damietta Oncology Institute. $(\mathrm{N}=45)$

\begin{tabular}{|l|l|}
\hline Job satisfaction factors & Mean\% \pm SD \\
\hline I - hygienic factors & \\
1-Salary and incentive & $40.0 \% \pm 13.3$ \\
2-Work environment and safety & $29.0 \% \pm 8.0$ \\
3 - Internal relations & $33.8 \% \pm 10.0$ \\
4- Degree of supervision and its type & $47.3 \% \pm 15.6$ \\
5- Hospital administration policy & $24.3 \% \pm 12.3$ \\
\hline Total of hygienic factors & $\mathbf{3 0 . 6 \%} \pm \mathbf{8 . 3}$ \\
\hline - motivating factors & \\
1- Work achievement & $52.3 \% \pm 0.90$ \\
2- Appreciation in work & $34.3 \% \pm 12.3$ \\
3-Work challenge & $38.14 \% \pm 13.37$ \\
4-Responsibilities & $24.3 \% \pm 28.0$ \\
5-Advancement and skills development & $20.3 \% \pm 11.6$ \\
\hline Total of motivating factors & $\mathbf{3 5 . 2 3 \%} \mathbf{6 . 5 5}$ \\
\hline Total job satisfaction & $\mathbf{3 1 . 7 6 \%} \pm \mathbf{5 . 6 4}$ \\
\hline
\end{tabular}

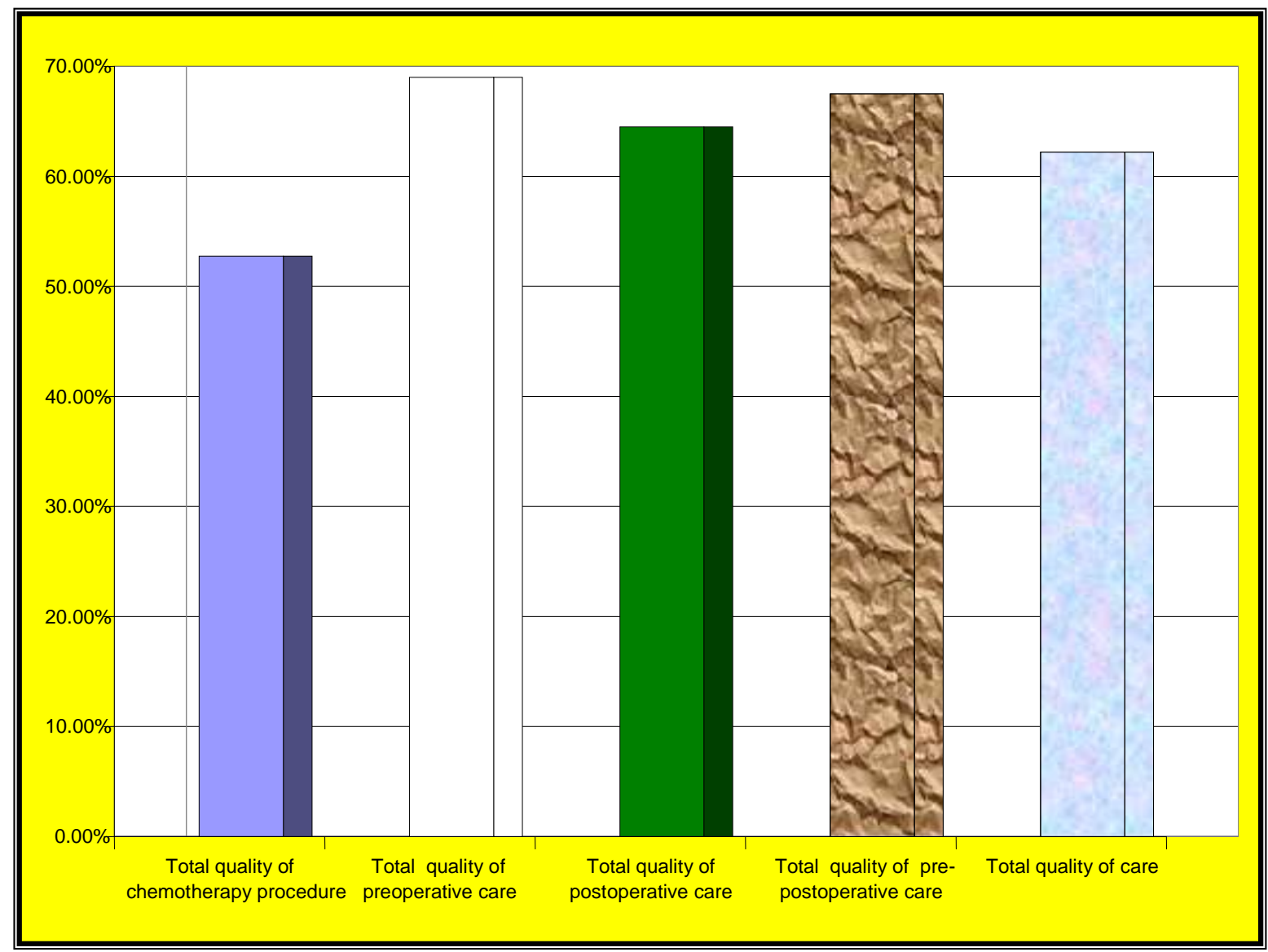

Figure (1): Total mean percentage of the total quality of nursing care among participating nurses at Damietta Oncology Institute. 
Table (3): The relationship between job satisfaction and quality of nursing care among participating nurses at Damietta Oncology Institute.

\begin{tabular}{|c|c|c|c|c|c|c|c|c|c|c|c|c|c|}
\hline \multirow{3}{*}{ Job satisfaction } & \multicolumn{4}{|c|}{ Preoperative care } & \multicolumn{4}{|c|}{ Postoperative care } & \multirow[t]{2}{*}{ Total } & \multicolumn{3}{|c|}{$\begin{array}{l}\text { Chemotherapy } \\
\text { administration }\end{array}$} & \multirow[t]{2}{*}{$\begin{array}{l}\text { Total } \\
\text { quality }\end{array}$} \\
\hline & $\mathbf{1}^{\mathrm{a}}$ & $2^{b}$ & $\mathbf{3}^{\mathrm{c}}$ & $\begin{array}{l}\text { Tota } \\
1\end{array}$ & $\mathbf{1}^{\mathrm{d}}$ & $2^{\mathrm{e}}$ & $3^{f}$ & Total & & $\mathbf{1}^{\mathrm{g}}$ & $2^{\mathrm{h}}$ & Total & \\
\hline & $\mathbf{r}$ & $\mathbf{r}$ & $\mathbf{r}$ & $\mathbf{r}$ & $\mathbf{r}$ & $\mathbf{r}$ & $\mathbf{r}$ & $\mathbf{r}$ & $\mathbf{r}$ & $\mathbf{r}$ & $\mathbf{R}$ & $\mathbf{r}$ & $\mathbf{R}$ \\
\hline Hygienic factors & 0.23 & 0.06 & 0.30 & 0.08 & 0.07 & 0.10 & 0.09 & 0.09 & 0.11 & 0.02 & 0.18 & 0.29 & 0.12 \\
\hline Salary and incentive & $0.44 *$ & 0.16 & 0.19 & 0.35 & 0.25 & 0.31 & -0.38 & 0.05 & 0.25 & 0.26 & 0.13 & -0.15 & $0.45 *$ \\
\hline Work environment \& safety & 0.11 & 0.15 & 0.22 & 0.23 & -0.05 & 0.09 & -0.14 & -0.04 & 0.11 & $0.56 *$ & 0.32 & -0.26 & 0.11 \\
\hline Internal relationships & -0.03 & 0.16 & 0.09 & 0.13 & -0.32 & -0.11 & -0.19 & -0.28 & -0.12 & -0.03 & -0.27 & $0.43 *$ & -0.03 \\
\hline Degree of supervision & -0.09 & 0.28 & 0.12 & 0.21 & -0.35 & -0.26 & -0.11 & -0.32 & -0.09 & 0.24 & 0.05 & -0.26 & -0.09 \\
\hline $\begin{array}{l}\text { Hospital administration } \\
\text { policy }\end{array}$ & 0.18 & 0.09 & -0.05 & 0.11 & $0.44 *$ & $0.45 *$ & -0.09 & $0.45 *$ & -0.26 & -0.01 & -0.19 & -0.35 & 0.18 \\
\hline Motivating factors & 0.16 & 0.12 & 0.02 & 0.03 & 0.02 & 0.14 & 0.10 & 0.003 & 0.02 & 0.05 & 0.22 & $0.48 *$ & $0.82 *$ \\
\hline Work achievement & -0.39 & -0.26 & 0.13 & -0.26 & -0.11 & 0.22 & -0.11 & 0.40 & -0.14 & -0.13 & -0.37 & $0.46 *$ & -0.39 \\
\hline Appreciation in work & 0.38 & -0.12 & -0.07 & 0.02 & -0.21 & -0.32 & 0.27 & -0.09 & -0.06 & 0.33 & 0.06 & -0.39 & 0.38 \\
\hline Work challenges & -0.02 & 0.08 & -0.16 & -0.01 & 0.09 & -0.01 & -0.05 & -0.03 & -0.03 & -0.21 & -0.26 & -0.15 & -0.02 \\
\hline Responsibilities & -0.04 & 0.05 & -0.02 & -0.02 & -0.18 & -0.21 & 0.19 & -0.07 & -0.04 & 0.07 & -0.09 & -0.15 & -0.04 \\
\hline Work \& skills development & 0.37 & -0.20 & 0.12 & 0.05 & 0.14 & 0.23 & 0.07 & 0.22 & 0.20 & 0.19 & -0.05 & -0.37 & 0.37 \\
\hline Total job satisfaction & 0.25 & 0.05 & 0.013 & 0.17 & -0.25 & -0.09 & -0.08 & -0.18 & -0.02 & 0.23 & -0.11 & $0.54 *$ & -0.24 \\
\hline
\end{tabular}

${ }_{b}^{a}$ preoperative care on admission

${ }^{b}$ preoperative day before surgery

${ }_{d}^{c}$ preoperative day of surgery

${ }^{d}$ postoperative immediate care after surgery

${ }^{e}$ postoperative care of body vital system

${ }^{f}$ postoperative health education before discharge

${ }^{g}$ pretreatment intervention

${ }^{h}$ administration of chemotherapy

Preoperative: 1= on admission, 2= day before surgery, 3= day of surgery

Postoperative: $1=$ immediate care after surgery, $2=$ care of body vital system, $3=$ health education before discharge

Chemotherapy: $1=$ pretreatment intervention, $2=$ administration of chemotherapy

\section{DISCUSSION:}

Job satisfaction and quality of care are important issues for hospital administration. Quality of care depends on the job satisfaction of the nurses. As the nurses' satisfaction is a must for achieving a higher level of performance, therefore, the management's responsibility is to frequently ensure a high level of job satisfaction for the nurses (Akumari, 2008; Khaliq et al, 2011). In addition, Larson (2013) stated that any health care organization seeking to consistently achieve high-quality patient outcomes should take a good hard look at their nursing staff. If the nurses feel engaged, empowered and satisfied with their working environment, their patients are more likely to do well, too. 
The results presented here show that the total job satisfaction of the participating nurses was the least level. In this regards, work achievement scored the highest mean percentage of nurses' satisfaction level. This finding is a disagreement with Ibrahim (2009) who found that work achievement scored lower mean percentage of nurses' satisfaction. Whereas, advancement and skills development scored the least mean percentage of nurses' satisfaction. In this regard, Hill (2013) emphasized the importance of advancement and skills development for nurses to be more satisfied with their current job if they see a path available to acquire more advanced skills that will lead to the chance of promotion.

The total quality of nursing care showed a moderate level among participating nurses. In this regard, total quality of preoperative care was the highest mean percentage whereas total quality of chemotherapy administration was the least mean percentage. This finding may be referred to the presence of a written checklist for preparation of preoperative patient whereas there is no written checklist for chemotherapy administration.

Concerning the relationship between total job satisfaction and total quality of care among participating nurses. It was found that there was no correlation between total job satisfaction and quality of care. However, there was a statistically significant difference correlating between salary and incentive as hygienic factors of job satisfaction and the quality of preoperative care on admission in addition to their correlation to the total quality of care. In this regards, Ford et al. (2012) stated that money can be offered as an incentive or a reward for quality of nurses' performance in a variety of ways, and can be used to satisfy a variety of needs.

It was also found that there is a significant correlation between work environment and safety as hygienic factors of job satisfaction and quality of pretreatment intervention of chemotherapy administration. This finding is in the line with Siddiqui (2013) who stated that there is a relationship between the nursing practice environment and quality of nursing care. Improvement in nursing practice environment may lead to similar consequences in quality of nursing.

Moreover, there was a significant correlation between hospital administration policy as hygienic factor and the total quality of postoperative care. In this regard, Aiken, Clark and Sloane (2009) stated that organizational climate in hospitals and specifically organizational support for nursing care that is potentially modifiable have been an undervalued determinant of poor patient outcomes. 


\section{CONCLUSION:}

From the findings of the current study, it is concluded that there is no significant relationship between nurses' job satisfaction and quality of nursing care whereas there is a significant relationship between the total quality of nursing care and total motivating factor in addition to its relationship to salary and incentive as hygienic factors of job satisfaction.

\section{RCOMMENDATIONS:}

\section{For nurses' job satisfaction:}

- Clearly formulated promotion policies and salary scales for different staff nurses' ranks should be available to all professional nurses. This could reduce confusion and the levels of no satisfaction with the most important extrinsic (salary) and intrinsic (promotion) factors influencing nurses' levels of job satisfaction.

- Hospital administration must help nurses feel a legitimate sense of importance through responsibility delegation.

\section{For quality of nursing care:}

- Effective training about preparation of patients before chemotherapy administration. -Hospital administration must provide adequate skills training for postoperative care and equip every unit with book procedures for nurses.

\section{REFERENCES}

Aiken, LH., Clarke, S.P. \& Sloane, D.M. (2009).Hospital staffing, organization, and quality of care. International Journal for Quality in Health Care, 50(5), P.p. 14. Retrieved from : www. Nursing. upenn .edu/... / International Publications

Akumari, P. (2008). The impact of job satisfaction on job performance. an empirical analysis, 17 (6), P.p. 89 . Retrieved from: 202 .11. 2. 113 / SEBM / ronso / ... / 08 PUSHPAKUMARI . pd.

Clancy, C.M. (2009). What is health care quality and who decides? Department of Health and Human Services. Agency for Health Care Research, (3), P.p. 2. Retrieved from: www. hhs. gov/asl/testify/2009/03/t20090318b.html

Fayed, L. (2009).Method of treatment for cancer: standard treatment for cancer. About.com Cancer,25(3), P.p. 1.Retrieved from: Cancer . about . com / od / treatment options / a / options.htm 
Ford, R.C., Sturman, M.C. \&Heaton, C.P. (2012).Managing quality service in hospitality (International edition.).Cengage learning international offices, Canada, P.p. 99-103, 234,236, 256, 258.

George, J.M. and Jones, G.R. (2008).Understanding and Managing Organizational behavior (5nd ed.). New Jersey: Pearson/Prentice Hall, P.p. 78.

Hill, B. (2013). What are the factors affecting job satisfaction: opportunity for advancement. HEARST newspapers, (104), P.p. 5. Retrieved from : www . International conference.com.my / .../ icmef

Ibrahim, H.M.A. (2009).Relation between nurses' job satisfaction and quality of their performance in Abu- Kabier general hospital (Published thesis, Zagizig University, Abu- Kabier), P.p. 58, 70, 73, and 78.

Institute of Medicine. (2013).Delivering high quality cancer care: Charting a new course for a system in crisis (information series. 15). Washington, P.p. 3.Retrieved from: www. Iom.edu/quality cancer care

Khaliq, J., Rehman, M.Z. \&Rashid, M. (2011). The role of human resource management and nurses' job satisfaction in medical service organizations. Journal of Business Management, 5 (3), P.p. 7.Retrieved from: http://www.academicjournals.org/AJBM

Larson, J.(2013). Why nurses' job satisfaction matters to patients. Nursing news.com,12(3), P.p.10.

Retrieved from: www.nurse zone.com/nursing news-events/more-news.aspx

Maria, M., Pavlos, S., Eleni, M. \&Thamme, K. (2010). Greek registered nurses' job satisfaction in relation to work-related stress: A study on Army and Civilian Runs. Global Journal of Health Science, 2(1), P.p. 49. Retrieved from:www.ccsenet.org/gjhs

Marquis, B.L. and Huston, C. J. (2009).Leadership roles and management functions in nursing.(6thed.).New York: Walters Kluwer. Lippincott Williams, P.p. 423, 425,429 .

Medical Education Institute. (2012).Performance / quality improvement: the definition of health care quality and the institute of medicine. USA, P.p. 1. Retrieved from: www.peerpt.com/website/index.php?option 
Nigy, M.N. (2006).A study on job satisfaction of nursing staff in a multi-specialty hospital (Published master's thesis, The Rajiv Gandhi University, hospital administration), P.p. 1, 4, and 53. Retrieved from: http://www_noapdf.com

Siddiqui, N. (2013). Investing in human relations for healthy nursing practice environment: nurses' job satisfaction and quality of nursing care. American Journal of Nursing Research, 1(1), P.p. 19. 


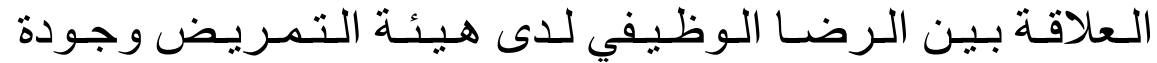

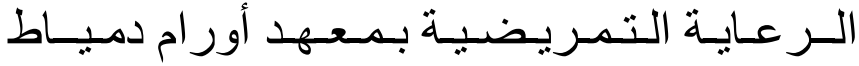

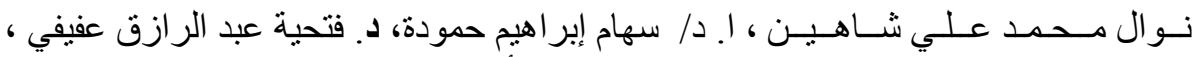

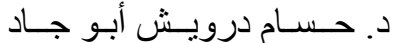

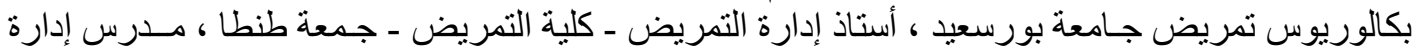

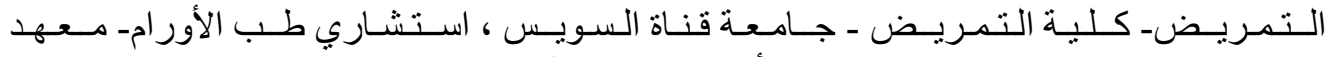

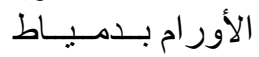

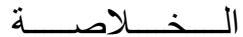

انخفاض مستوى الرضا الوظيفي لدى هيئة التمريض يعد من اهم الاسباب التي تؤدى الى ترك المهنة و ذلك

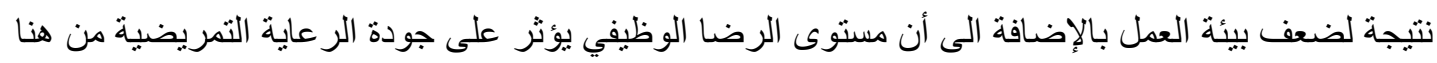
يهدف البحث الى دراسة العلاقة بين الرضا الوظيفي لدى هيئة التمريض وجودة الرعاية التمريضية في معهد

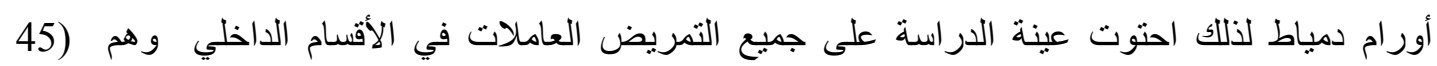
ممرضة) وقد تم جمع البيانات عن طريق ثلاث استمار ات ، استمارة الرضا الوظيفي وتتكون من 92 عنصر ، استمارة اعطاء العلاج الكيماوي وتضم 35 عنصر ا، استمارة رعاية المريض قبل وبعد الجر احة وتتكون من 6 نقاط رئيسية تضم 76 عنصر ا. وقد أسفرت نتائج هذه الدر اسة على أن الرضا الوظيفي لدى هيئة التمريض يمثل نسبة 76. 31 \% و هذه النسبة تمثل مستوى منخفض من الرضا الوظيفي وأيضا نسبة مستوى جودة الرعاية التمريضية تمثل 2. 62 \% و هذه النسبة تمثل مستوى متوسط من جودة الرعاية التمريضية ، من هنا يتضح انه

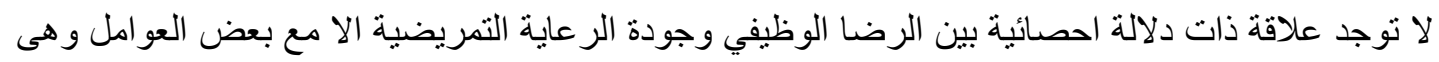

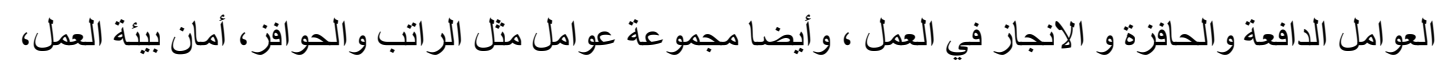

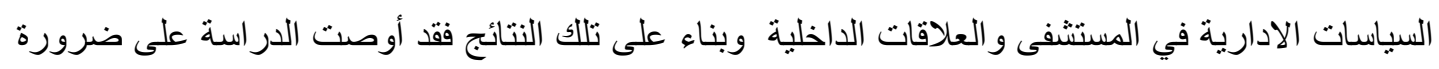
وضع نظام ثابت وو اضح للترقي في العمل ، اعطاء تفويض بالمسؤولية المناسبة لهيئة التمريض لأداء عملهم بسهولة ، وكذللك اعطاء أجور مناسبة لتغطى تكاليف المعيثة، توفير بيئة عمل أمنة لهيئة التمريض. أما بالنسبة لجودة الرعاية التمريضية فقد أوصت نتائج البحث على توفير برنامج تدريبي ثابت على المهار ات و السياسات

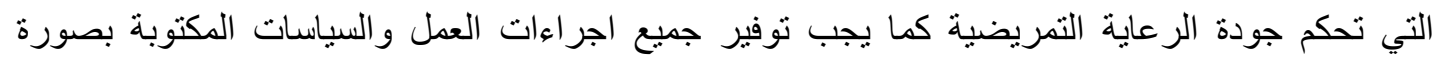

